\title{
Evaluasi Rasionalitas Penggunaan Obat Neuroprotektif pada Pasien Stroke Iskemik di Rumah Sakit Stroke
} Nasional Bukittinggi

\section{Rationality of Neuroprotective Drug Use in Ischemic Stroke Patients at the Bukittinggi National Stroke Hospital}

Dita Permatasari, Dian Ayu Juwita*, Rahmi Yosmar, Julio Fajar Rahmat Illahi

Bagian Farmakologi dan Farmasi Klinis, Fakultas Farmasi, Universitas Andalas, Padang, Indonesia

*Corresponding author: dianayujuwita@phar.unand.ac.id

Submitted: 15 November 2020

Accepted: 19 Desember 2020

Published: 29 Agustus 2021

\begin{abstract}
Background: Ischemic stroke is caused by local thrombus formation or embolism that occurs in the cerebral arteries. This causes a lack of blood flow so that the oxygen needed by brain tissue is also reduced. The incidence of ischemic stroke reaches $87 \%$, the highest number of all other stroke cases. Neuroprotective drugs are one of the therapies aimed at reducing nerve damage caused by ischemic strokes. Objective: This study aimed to determine the demographic characteristics of ischemic stroke patients, patterns of drug used and the rationality for neuroprotective medicines of ischemic stroke patients. Methods: This study was designed as observational in which the data were collected from from inpatient medical record data in 2019 as many as 280 patients retrospectively. The data obtained will be compared to predetermined treatment standards. Results: The results showed that the greatest number of ischemic stroke patients was male by $63.2 \%$ with an age range of 55 - 64 years by $39 \%$. The highest percentage of the latest educational status is high school reaching 47.1\%, followed by the most employment status, namely IRT, with $28.2 \%$. The most widely used neuroprotective drug is citicoline at $53.2 \%$, with intravenous administration routes reaches $51.8 \%$. The evaluation of neuroprotective drugs' rationality in the hospital included $100 \%$ appropriate indication, $99.3 \%$ appropriate patient, $100 \%$ appropriate medication, 97.9\% appropriate dose, and 99.3\% appropriate drug administration. Conclusions: The incidence of irrational therapy was still found in 8 patients, spread over on appropriate patient, right dose, and right drug administration.
\end{abstract}

Keywords: ischemic stroke, neuroprotective drug, rationality

\begin{abstract}
Abstrak
Pendahuluan: Stroke iskemik disebabkan oleh pembentukan trombus lokal atau emboli yang terjadi pada arteri serebral. Hal tersebut menyebabkan kurangnya aliran darah sehingga oksigen yang dibutuhkan oleh jaringan otak juga berkurang. Angka kejadian stroke iskemik mencapai $87 \%$ yang merupakan angka tertinggi dari seluruh kasus stroke lainnya. Obat neuroprotektif termasuk salah satu terapi yang ditujukan untuk mengurangi kerusakan saraf yang disebabkan oleh serangan stroke iskemik. Tujuan: Tujuan penelitian ini untuk mengetahui karakteristik demografi pasien stroke iskemik, pola penggunaan obat dan rasionalitas obat neuroprotektif pada pasien stroke iskemik. Metode: Metode penelitian ini adalah observasional yang diambil dari data rekam medik instalasi rawat inap $(n=280)$ tahun 2019 secara retrospektif. Data yang diperolah akan dibandingkan terhadap standar pengobatan yang telah ditetapkan. Hasil: Hasil penelitian menunjukan bahwa pasien stroke iskemik terbanyak yaitu laki-laki sebesar 63,2\% dengan rentang usia 55 - 64 tahun sebesar 39\%. Persentase tertinggi dari status pendidikan terakhir yaitu SLTA mencapai $47,1 \%$. diikuti dengan status pekerjaan terbanyak yaitu IRT sebesar 28,2\%. Penggunaan obat neuroprotektif paling banyak digunakan adalah sitikolin sebesar 53,2\% dengan rute pemberian secara intravena mencapai 51,8\%. Evaluasi rasionalitas penggunaan obat neuroprotektif pada rumah sakit tersebut antara lain, tepat indikasi $100 \%$, tepat pasien $99,3 \%$, tepat obat $100 \%$, tepat dosis $97,9 \%$, dan tepat frekuensi pemberian
\end{abstract}


obat 99,3\%. Kesimpulan: Kejadian terapi tidak rasional masih ditemukan pada 8 orang pasien tersebar pada indikator tepat pasien, tepat dosis dan tepat frekuensi pemberian obat.

Kata kunci: obat neuroprotektif, rasionalitas, stroke iskemik

\section{PENDAHULUAN}

Stroke adalah penurunan sistem saraf pusat secara tiba-tiba yang berlangsung selama 24 jam dan dapat berakhir kematian (Fagan \& Hess, 2019). Di Indonesia, diperkirakan penduduk yang terdiagnosa stroke sekitar 500.000 orang setiap tahunnya, kemudian sekitar 125.000 orang meninggal dunia dan sisanya mengalami kecacatan akibat serangan stroke (Siti \& Chatarina, 2016). Hasil Riset Kesehatan Dasar (RISKESDAS) Kementerian Kesehatan di tahun 2018 menunjukan adanya peningkatan prevalensi kejadian stroke di Indonesia dari 7 per 1000 penduduk pada tahun 2013 meningkat menjadi 10,9 per 1000 penduduk pada tahun 2018 berdasarkan diagnosis dokter (Kementerian Kesehatan RI, 2018). Berdasarkan penyebab terjadinya, stroke terbagi atas stroke iskemik dan hemoragik. Stroke iskemik disebabkan oleh pembentukan trombus lokal atau emboli yang terjadi pada arteri serebral. Hal tersebut menyebabkan kurangnya aliran darah sehingga oksigen yang dibutuhkan oleh jaringan otak juga berkurang. Angka kejadian stroke iskemik mencapai $87 \%$ yang merupakan angka tertinggi dari seluruh kasus stroke lainnya (Fagan \& Hess, 2019).

Stroke dapat menyebabkan gangguan fisik atau disabilitas, dimana bagian tubuh itu tidak akan mampu berfungsi sebagaimana mestinya (Alldredge dkk., 2013). Ketidakmampuan ini terjadi karena kerusakan sel-sel otak akibat stroke yang dapat menyebabkan kecatatan fungsi antara lain sensorik, motoric dan kognitif (Wittenauer \& Smith, 2012). Gangguan fungsi kognitif yang muncul umumnya kelainan persepsi, atensi, bahasa, memori, emosi, dan fungsi eksekutif (Menteri Kesehatan RI, 2010). Gangguan kognitif dapat diatasi dengan penggunaan obat neuroprotektif. Tujuan terapi neuroprotektif untuk mengurangi kerusakan saraf yang disebabkan oleh serangan stroke iskemik (Pathan, 2012). Di Indonesia, neuroprotektif yang sering digunakan adalah pirasetam dan sitikolin (Perhimpunan Dokter Spesialis Saraf Indonesia (PERDOSSI), 2016).

Pada beberapa penelitian sebelumnya ditemukan ketidaktepatan indikasi, dimana obat neuroprotektif diberikan kepada pasien stroke hemoragik yang seharusnya diberikan kepada pasien stroke iskemik (Nurhaini dkk., 2018). Selain itu, ditemukan ketidaktepatan dosis obat neuroprotektif pada pasien stroke iskemik yang mencapai 35\% (Febriola, 2019). Penelitian lainnya di RSUP DR. M. Djamil Padang juga menunjukkan ketidaktepatan dosis terkait penggunaan obat neuroprotektif pada pasien stroke iskemik (Zhafira, 2018).

Salah satu bentuk pelayanan farmasi klinik yang menjadi tanggung jawab seorang apoteker adalah evaluasi penggunaan obat (EPO), dimana salah satu yang perlu dievaluasi yaitu kerasionalan penggunaan obat guna memberikan terapi yang efektif, efisien dan aman bagi pasien. Tujuan penelitian ini adalah untuk mengetahui karakteristik demografi pasien stroke iskemik, mengetahui pola penggunaan obat neuroprotektif, dan mengetahui rasionalitas penggunaan obat neuroprotektif yang meliputi ketepatan indikasi, obat, pasien, dosis, serta frekuensi pemberian obat pada pasien stroke iskemik.

\section{METODE}

\section{Rancangan penelitian}

Metode pada penelitian ini adalah observasional dengan membandingkan data yang diperolah dengan standar pengobatan yang telah ditetapkan. Data diambil secara restrospektif. Data yang diambil yaitu data rekam medis di Instalasi Rawat Inap RSSN Bukittinggi pasien stroke iskemik tahun 2019 sebanyak 280 pasien dengan menggunakan metode systematic random sampling.

\section{Kriteria penderita}

Kriteria inklusi yaitu pasien dengan diagnosa utama stroke iskemik yang menerima terapi obat neuroprotektif sedangkan untuk kriteria eksklusi yaitu pasien dengan diagnosa utama stroke iskemik yang menerima terapi obat neuroprotektif namun dengan data rekam medik yang tidak lengkap dan tidak jelas.

\section{Pengambilan data}

Data yang dikumpulkan berupa data demografi (jenis kelamin, umur, pendidikan terakhir, pekerjaan), data klinik (diagnosa, riwayat penyakit, dan penyakit penyerta pasien) dan data penggunaan obat neuroprotektif (nama obat, dosis, frekuensi dan rute pemberian obat). Penelitian dilaksanakan dengan surat izin penelitian dari direktur rumah sakit dengan nomor DM.01.01/6/28/11/2020. 


\section{Penetapan standar penggunaan obat}

Kriteria pasien dikatakan sudah mendapatkan terapi obat neuroprotektif secara rasional apabila memenuhi indikator tepat indikasi, obat, pasien, dosis dan frekuensi. Standar penggunaan obat yang menjadi rujukan yaitu Guideline stroke tahun 2011 oleh Perhimpunan Dokter Spesialis Saraf Indonesia (PERDOSSI), Clinical pathway dan panduan klinik pasien stroke iskemik RSSN Bukittinggi, Buku Martindale "The Complete Drug Reference" edisi 36 (Sweetman, 2009), serta Buku "Pedoman Tata Laksana Cedera Otak" edisi kedua (Tim, 2014).

\section{Analisis data}

Data dianalisis secara deskriptif, kemudian data ditabulasikan dan dibandingkan terhadap standar pengobatan yang telah ditetapkan. Hasil analisis akan menunjukkan persentase rasionalitas yaitu persentase masing-masing dari tepat indikasi, tepat obat, tepat pasien, tepat obat dan tepat frekuensi pemberian obat penggunaan obat neuroprotektif pada pasien stroke iskemik.

\section{HASIL DAN PEMBAHASAN}

Dari 280 sampel yang didapatkan, distribusi pasien stroke iskemik terbanyak sesuai hasil pada Tabel 1 yaitu pada laki-laki $(63,2 \%)$, rentang umur 56 - 65 tahun (39\%), pendidikan terakhir Sekolah Lanjutan Tingkat Atas (SLTA) $(47,1 \%)$ dan pada pekerjaan Ibu Rumah Tangga (IRT) $(28,2 \%)$. Hasil penelitian menunjukkan bahwa pasien stroke iskemik terbanyak yaitu pada lakilaki. Kebiasaan yang sering dilakukan laki-laki seperti merokok dan mengonsumsi alcohol dapat memicu terjadinya stroke iskemik (Sultradewi dkk, 2019). Pada wanita, terdapat hormone estrogen yang memiliki efek positif terhadap sirkulasi serebral yang dapat melindungi wanita dari kejadian stroke iskemik sehingga wanita lebih sedikit menjadi penderita dibandingkan laki-laki (Goldstein dkk., 2011; Lisabeth \& Bushnell, 2012). Pada kategori kelompok umur, paling banyak ditemukan adalah pasien pada rentang umur 56 - 65 tahun dikarenakan semakin bertambahnya umur, maka semakin kurang optimalnya fungsi organ termasuk pembuluh darah otak (Kristiyawati dkk, 2009).

Tabel 1. Karakteristik demografi pasien stroke iskemik $(n=280$ orang)

\begin{tabular}{lcc}
\hline \multicolumn{1}{c}{ Kategori } & Jumlah Pasien (orang) & Persentase (\%) \\
\hline Jenis kelamin & & \\
- Laki-laki & 177 & 63,2 \\
- Perempuan & 103 & 36,8 \\
\hline Kelompok Umur & & \\
- 5 - 11 tahun & 0 & 0 \\
- 12 - 16 tahun & 0 & 0 \\
- 17 - 25 tahun & 0 & 0 \\
- 26 - 35 tahun & 1 & 0,3 \\
- 36 - 45 tahun & 19 & 6,8 \\
- 46 - 55 tahun & 54 & 19,3 \\
- 56 - 65 tahun & 109 & 39 \\
- > 65 tahun & 97 & 34,6 \\
\hline Pendidikan & & \\
- Tidak Sekolah & 27 & 9,6 \\
- SD & 64 & 22,9 \\
- SLTP & 26 & 9,3 \\
- SLTA & 132 & 47,1 \\
- DIII & 9 & 3,2 \\
- DIV/S1 & 22 & 7,9 \\
\hline Pekerjaan & & \\
- PNS & 33 & 11,8 \\
- POLRI & 1 & 0,3 \\
- Swasta & 43 & 15,4 \\
- Pelajar/Mahasiswa & 0 & 0 \\
- Pedagang & 53 & 18,9 \\
- Supir & 1 & 0,3 \\
- Buruh & 55 & 19,6 \\
- Petani & 4 & 1,4 \\
- IRT & 79 & 28,2 \\
\hline & &
\end{tabular}


Untuk hasil penelitian pada kategori pendidikan tersebut dikaitkan dengan rendahnya pengetahuan seseorang, dimana informasi tentang kesehatan yang didapat pun akan berkurang sehingga kemampuan berperilaku suatu individu untuk mencapai kesehatan tidak optimal. Pekerjaan yang paling banyak ditemukan pada pasien stroke iskemik yaitu ibu rumah tangga (IRT). Hasil tersebut dikaitkan dengan rentannya seorang IRT mengalami kondisi stress dalam mengatur internal rumah tangga. Stress dapat dianggap sebagai salah satu faktor resiko yang paling berpengaruh terhadap terjadinya stroke (Adientya \& Handayani, 2012).

Berdasarkan Tabel 2, hasil penelitian menunjukkan obat neuroprotektif yang paling banyak diberikan pada pasien yaitu sitikolin $(53,6 \%)$. Selanjutnya, pada Tabel
3 menunjukkan hasil penelitian terkait dengan evaluasi rasionalitas penggunaan obat neuroprotektif. Didapatkan tepat indikasi sebesar $100 \%$ karena penggunaan obat neuroprotektif sudah sesuai dengan pedoman atau literatur yang digunakan yaitu bahwa obat neuroprotektif diberikan kepada pasien dengan indikasi stroke iskemik. Pada level neuronal, sitikolin akan menambah sintesis phosphatidylcholine yang dapat memperbaiki membrane sel. Selain itu, meingkatkan produksi glutathione yang berfungsi sebagai antioksidan endogen otak terhadap radikal bebas (Praja dkk., 2013). Sedangkan pirasetam bekerja dengan mengelilingi gugus polar fosfolipid membentuk ikatan obat-lipid yang berperan dalam memperbaiki fluiditas membran sel (Lutsep, 2015; Winblad, 2005).

Tabel 2. Pola penggunaan obat neuroprotektif ( $n=280$ orang)

\begin{tabular}{lcc}
\hline \multicolumn{1}{c}{ Nama Obat } & Jumlah Pasien (orang) & Persentase (\%) \\
\hline Sitikolin & 150 & 53,6 \\
Pirasetam & 125 & 44,6 \\
Sitikolin \& Pirasetam & 5 & 1,8 \\
\hline
\end{tabular}

Tabel 3. Evaluasi rasionalitas penggunaan obat neuroprotektif pada pasien stroke iskemik ( $\mathrm{n}=280$ orang)

\begin{tabular}{lcc}
\hline \multicolumn{1}{c}{ Indikator Rasionalitas } & Jumlah Kejadian & Persentase $(\%)$ \\
\hline Tepat Indikasi & 280 & 100 \\
Tepat Pasien & 278 & 99,3 \\
Tepat Obat & 280 & 100 \\
Tepat Dosis & 274 & 97,9 \\
Tepat Frekuensi & 278 & 99,3 \\
\hline
\end{tabular}

Pada indikator tepat obat juga didapatkan persentase ketepatannya sebesar $100 \%$ karena sudah sesuai dengan pilhan obat neuroprotektif yang tertera dalam Clinical Pathway atau panduan klinis yang dikeluarkan oleh RSSN Bukittinggi yaitu obat pirasetam dan sitikolin.

Pada indikator tepat pasien, ditemukan sebanyak 278 kejadian $(99,3 \%)$ yang dinyatakan tepat pasien. Terdapat dua kejadian dikategorikan tidak tepat pasien karena memiliki penyakit penyerta gangguan ginjal kronik yang tetap mendapatkan pirasetam dengan dosis normal. Pirasetam tidak seharusnya diberikan pada pasien dengan gangguan hati dan gangguan ginjal (Sweetman, 2009). Pirasetam diekresikan hampir 90\% di ginjal dalam bentuk fraksi obat yang utuh oleh karena itu pada pasien dengan gangguan ginjal perlu dilakukan penyesuaian dosis (Winblad, 2005; Drugbank, 2020). Prinsip penyesuaian dosis pirasetam adalah terapi optimal, namun meminimalisir kejadian toksisitas (ViaSosa dkk. 2013).

Pada ketepatan dosis, didapatkan 274 kejadian $(97,9 \%)$ dinyatakan tepat dosis. Sedangkan 2,1\% lainnya dinyatakan tidak tepat dosis karena tidak sesuai dengan pedoman penggunaan obat yang digunakan. Dalam pedoman tersebut, sitikolin harus diberikan dengan dosis 2 × $500 \mathrm{mg}$ dalam sehari dan pirasetam dengan dosis $2 \times 1200 \mathrm{mg}$ pada pasien stroke iskemik. Sebanyak empat pasien dinyatakan tidak tepat dosis karena mendapatkan terapi sitikolin dengan dosis $2 \mathrm{x}$ $250 \mathrm{mg}$. Sedangkan dua pasien lainnya mendapatkan terapi sitikolin dengan dosis 1 x $500 \mathrm{mg}$. Dosis obat yang diberikan dibawah dosis terapi yang terdapat pada pedoman.

Pada ketepatan frekuensi pemberian obat neuroprotektif, didapatkan hasil sebanyak 278 kejadian (99,3\%) dinyatakan tepat frekuensi. Sedangkan $0,7 \%$ lainnya dinyatakan tidak tepat frekuensi karena mendapatkan sitikolin dengan frekuensi satu kali dalam sehari. Hal tersebut tidak sesuai dengan pedoman penggunaan obat yang digunakan, dimana dalam pedoman tersebut sitikolin harus diberikan dua kali sehari dengan dosis $500 \mathrm{mg}$ secara intravena maupun oral. Sitikolin sampai saat ini masih memberikan manfaat pada stroke dengan frekuensi pemberian 2 - 3 
kali sehari (Perhimpunan Dokter Spesialis Saraf Indonesia, 2011).

\section{KESIMPULAN}

Penggunaan obat neuroprotektif pada pasien stroke iskemik di RSSN Bukitinggi masih ditemukan sepuluh kejadian terapi neuroprotektif yang tidak rasional pada delapan orang pasien tersebar pada indikator rasionalitas tepat pasien, tepat dosis dan tepat frekuensi pemberian obat. Ada dua dari delapan orang pasien tersebut yang mengalami dua kejadian terapi neuroprotektif tidak rasional sekaligus.

\section{UCAPAN TERIMA KASIH}

Penulis mengucapkan rasa terima kasih kepada seluruh pihak yang terlibat dan memberikan kontribusi yang berarti dalam penelitian ini.

\section{DAFTAR PUSTAKA}

Adientya, G. \& Handayani, F. (2012). Stres pada Kejadian Stroke. Diponegoro Journal of Nursing; $1 ; 183-188$.

Alldredge, B. K., Corelli, R. L., Ernst, M. E., Guglielmo, B. J., Jacobson, P. A., Kradjan, W. A. \& Williams, B. R. (2013). Koda-Kimble and Young's Applied Therapeutics: The Clinical Use of Drugs (Tenth Edit). Philadelphia: Lippincott Williams \& Wilkins, a Wolters Kluwer Business.

Drugbank. (2020). Drugbank : Piracetam by Drugbank. https:/go.drugbank.com/drugs/DB09210.

Accessed: 17 September 2020.

Fagan, S. C. \& Hess, D. C. (2019). Pharmacotherapy: A Pathophysiologic Approach, Chapter 20: Stroke (Tenth Edit). New York: Mc Graw Hill Education.

Febriola, N. T. F. (2019). Drug Related Problems pada Pasien Stroke Iskemik Rawat Inap di RSUD Ir. Soekarno Sukoharjo Tahun 2017. Skripsi; Fakultas Farmasi Universitas Muhammadiyah Surakarta, Surakarta.

Goldstein, L. B., Bushnell, C. D., Adams, R. J., Appel, L. J., Braun, L. T., Chaturvedi, S., Creager, M. A., Culebras, A., Eckel, R. H., Hart, R. G., Hinchey, J. A., Howard, V. J., Jauch, E. C., Levine, S. R., Meschia, J. F., Moore, W.S., Nixon, J. V. \& Pearson, T. A. (2011). Guidelines for the Primary Prevention of Stroke: A Guideline for Healthcare Professionals from the American Heart Association/American Stroke Association. Stroke; 42; 517-584.

Kementerian Kesehatan RI. (2018). Hasil Utama Riset Kesehatan Dasar (RISKESDAS). Jakarta:
Kementerian Kesehatan RI.

Kristiyawati, S. P., Irawaty, D. \& Hariyati, R. T. S. (2009). Faktor Risiko yang Berhubungan dengan Kejadian Stroke di Rumah Sakit Panti Wilasa Citarum Semarang. Jurnal Ilmu Keperawatan dan Kebidanan (JIKK); 1; 1-7.

Lisabeth, L., \& Bushnell, C. (2012). Stroke Risk in Women: The Role of Menopause and Hormone Therapy. The Lancet Neurology; 11; 82-91.

Lutsep, H. L. (2015). Neuroprotective Agents in Stroke Overview of Neuroprotective Agents. https://emedicine.medscape.com/article/1161422 -overview. Accessed: 9 September 2020

Menteri Kesehatan RI. (2010). Keputusan Menteri Kesehatan RI Nomor 263/Menkes/SK/II/2010 tentang Pedoman Rehabilitas Kognitif. Jakarta: Menteri Kesehatan RI.

Nurhaini, R., Akrom \& Jatiningrum, A. (2018). Gambaran Drug Related Problems (DRPs) pada Pasien Stroke Rawat Inap Rumah Sakit X di Yogyakarta. Artikel Dosen; Fakultas Farmasi Universitas Ahmad Dahlan, Yogyakarta.

Pathan, A. B. (2012). Therapeutic Applications of Citicoline and Piracetam as Fixed Dose Combination. Asian Journal of Biomedical and Pharmaceutical Sciences; 2; 15-20.

Perhimpunan Dokter Spesialis Saraf Indonesia. (2011). Guideline Stroke 2011. Jakarta: Perhimpunan Dokter Spesialis Saraf Indonesia.

Perhimpunan Dokter Spesialis Saraf Indonesia (PERDOSSI). (2016). Panduan Praktik Klinis Neurologi. Jakarta: Perhimpunan Dokter Spesialis Saraf Indonesia.

Praja, D. S., Hasmono, D. \& Syifa, N. (2013). Studi Penggunaan Obat Neuroprotektan pada Pasien Stroke Iskemik (Penelitian di Rumah Sakit Umum Dr. Saiful Anwar Malang). Pharmacy; 10; 147159.

Siti, A., \& Chatarina, U. W. (2016). Faktor Risiko Kejadian Stroke Usia Muda. Berkala Epidemiologi; 4; 62-73.

Sultradewi, K. N. M. T., Krismashogi, D. D. \& Fatmawati, H. (2019). Gambaran Faktor Risiko dan Tingkat Risiko Stroke Iskemik berdasarkan Stroke Risk Scorecard di RSUD Klungkung. Intisari Sains Medis; 10; 720-729.

Sweetman, S. C. (2009). Martindale: The Complete Drug Reference (Thirty-six). London: Pharmaceutical Press.

Tim, N. F. U. A. (2014). Pedoman Tatalaksana Cedera Otak (Guideline in Management of Traumatic 
Brain Injury) (Edisi Kedua). Surabaya: Fakultas Kedokteran Universitas Airlangga.

Via-Sosa, M. A., Lopes, N. \& March, M. (2013). Effectiveness of a Drug Dosing Service Provided by Community Pharmacists in Polymedicated Elderly Patients with Renal Impairment - a Comparative Study. BMC Family Practice; 14; 96.

Winblad, B. (2005). Piracetam: a Review of Pharmacological Properties and Clinical Uses. CNS Drug Reviews; 11; 169-182.
Wittenauer, R. \& Smith, L. (2012). Priority Medicines for Europe and the World "A Public Health Approach to Innovation" Background Paper "Ischaemic and Haemorrhagic Stroke". Geneva: WHO.

Zhafira, D. (2018). Kajian Penggunaan Obat Neuroprotektif pada Pasien Stroke Iskemik di Instalasi Rawat Inap Neurologi RSUP Dr. M. Djamil Padang (Universitas). Skripsi; Fakultas Farmasi Universitas Andalas, Padang. 